JOHN G. BUTCHER

\title{
Resink revisited
}

\section{A note on the territorial waters of the self-governing realms of the Netherlands Indies in the late 1800s}

A distinctive feature of the constitutional structure of the Netherlands Indies was the division between the areas directly ruled by the government in Batavia and the 'self-governing' realms that were tied to the Netherlands by treaties or contracts but retained some degree of autonomy. ${ }^{1}$ In a series of articles written between 1950 and 1964 G.J. Resink argues that as late as 1910 many self-governing realms in fact retained their sovereignty and had relations with the government in Batavia that were international in character. Central to his argument is the assertion that these realms had their own territorial waters, for the possession of territorial waters may be seen as one of the attributes of state sovereignty. 'Not one maritime territory encompassed all the islands in a single legal system', he writes, 'but many territorial waters washed the land territories of many states and realms.' (Resink 1969:336.) With such language he conjures up a vast maritime world characterized by 'a dust cloud of sovereignties'. ${ }^{2}$ The purpose of this note is to answer the seemingly simple question of whether the self-governing realms did in fact have territorial waters at that time. I will begin by identifying what I see as problems in Resink's argument.

Resink does not offer a great deal of evidence of the multitude of territorial waters that he claims existed in the Netherlands Indies. This is hardly surprising, however, for as he makes clear the government in Batavia did little to

1 I thank Robert Elson, John Gullick, Gerry van Klinken, Ruth McVey, Carl Trocki, and an anonymous reader for this journal for reading a draft of this article and offering many valuable suggestions. I have made some changes in light of their comments but plan to explore the issues they raise more deeply in later publications. I am extremely grateful to the staff of the Nationaal Archief in The Hague for their assistance in locating and copying materials in the Ministry of Colonies archives.

2 Resink 1968:335. The phrase comes from a lecture given by Frederik M. van Asbeck, who coined it to characterize the political situation in 'the German principalities, the Swiss cantons, and the Italian states before their consolidation'.

JOHN G. BUTCHER is Associate Professor at the Department of International Business and Asian Studies, Griffith University. He holds a PhD from the University of Hull. He is the author of The British in Malaya, 1880-1941; The social history of a European community in colonial South-East Asia, Kuala Lumpur: Oxford University Press, 1979, and The closing of the frontier; A history of the marine fisheries of Southeast Asia c. 1850-2000, Singapore: Institute of Southeast Asian Studies, Leiden: KITLV Press, 2004. Professor Butcher may be contacted at J.Butcher@griffith.edu.au. 


\title{
STAATSBLAD VAN NEDERLANDSCH-INDIË.
}

\author{
No. 4. PARELVISSCHERIJ. Regelen voor het visschen naar parel- \\ schelpen, paarlemoerschelpen $\frac{\text { en }}{\text { of }}$ tripang, binnen \\ den afstand van niet meer dan drie Engelsche zee- \\ mijlen van de kusten van Nederlandsch-Indië.
}

\section{IN NAAM DER KONINGIN!}

DE GOUVERNEUR-GENERAAL VAN NEDERLANDSCH-INDIË,

\author{
Den Raad van Nederlandsch-Indië gehoord:
}

Allen, die deze zullen zien of hooren lezen, Saluut!

doet te weten:

Dat Hij, het wenschelijk achtende algemeene regelen vast te stellen voor het visschen naar parelschelpen, paarlemoerschelpen $\frac{\text { en }}{\text { of }}$ tripang binnen den afstand van niet meer dan drie Engelsche zeemijlen van de kusten van Nederlandsch-Indië;

Lettende op de artikelen 20,27, 29, 31 en 33 van het Reglement op het beleid der Regeering van Nederlandsch-Indië;

Heeft goedgevonden en verstaan:

Met intrekking van de ordonnantie van 5 October 1893 (Staatsblad n! 261), te bepalen:

\section{Artikel 1.}

(1) Het visschen naar parelschelpen, paarlemoerschelpen $\frac{\text { en }}{\text { of }}$ tripang binnen den afstand van niet meer dan drie Engelsche zeemijlen van de kusten van Nederlandsch-Indië is, behoudens de in het eerste lid van artikel 2 bedoelde uitzondering, uitsluitend geoorloofd aan hen die het recht daartoe op den voet dezer ordonnantie kebben verkregen.

(2) Onder visschen naar de in de vorige alinea genoemde zeeproducten wordt in deze ordonnantie verstaan elke handeling strekkende om parelen, paarlemoer $\frac{\text { en }}{\text { of }}$ tripang uit de zee op te halen, onverschillig welke middelen, toestellen of werktuigen daartoe worden aangewend.

(3) De in deze ordonnantie bedoelde afstand van drie Engelsche zeemijlen wordt gerekend van de laagwaterlijn langs de kusten der eilanden, behoorende tot Nederlandsch-Indië.

\section{Artikel 2.}

(1) Aan de Inlandsche bevolking blijft het recht om naar de in artikel 1 genoemde zeeproducten te visschen onverkort verzekerd; voor

Statute no. 4, Staatsblad van Nederlandsch-Indië, 1902 
recognize territorial waters along the coasts of the areas it ruled directly, let alone trying to identify any claims that self-governing realms might have had until Australian pearl-shellers burst into the eastern part of the archipelago in the 1880s. Thus, aside from citing a few authorities on adat (customary) law, Resink relies on an imaginative reading of statutes and supplements to these statutes that, in his view, demonstrate that self-governing realms had territorial waters. The two most important documents for Resink are statute no. 4 of 1902 and supplement 7295 of 1910 . Statute no. 4 regulated the pearl, pearlshell, and sea cucumber (tripang) fisheries of the Netherlands Indies and set out the conditions under which the governor-general could farm out the right to conduct these fisheries, while supplement 7295 provided a commentary on that statute and a number of related documents. For Resink the crucial section of statute no. 4 is the following paragraph:

In making these decisions [about whether to farm out the right to undertake pearlshell and other fisheries], consideration must be given not only to the interests of the native people of the district or land to whose zeegebied ['sea territory', 'sea area', or 'sea jurisdiction'] the relevant fishing ground belongs but also, as far as needed, those of the people of neighbouring districts or lands and equally those of the orang laut ['sea people'] who may ordinarily carry out their work in that fishing ground. ${ }^{3}$

According to Resink, this paragraph shows that 'principalities [...] could have maritime jurisdiction'. It seems to me that this interpretation is hardly convincing, for it is not altogether clear whether the use of the word zeegebied implies some form of jurisdiction over the sea on the part of a self-governing realm or simply provides a way of referring to the waters where the fishing grounds were located. But Resink then makes use of supplement 7295 to reinforce his interpretation. This supplement reproduces a letter the first government secretary wrote to the resident Zuider- en Oosterafdeeling van Borneo (eastern and southern districts of Borneo) concerning a request by a ' $\mathrm{Mr} \mathrm{X}^{\prime}$ to fish for sponges in waters off the coast of Gunung Tabur, a self-governing realm in eastern Borneo. This letter emphatically reminds the resident that in 1902 the Netherlands government decided that the right 'to the strip of sea out to three English sea miles from the coasts of a self-governing land' rested 'simply and solely' with the government. In other words, such realms had no territorial waters. ${ }^{4}$ The letter then states that the government also decided

3 Staatsblad van Nederlandsch-Indië, 1902, no. 4, article 2, paragraph 5.

4 Several statutes issued during the remainder of the colonial period reinforced this principle. The regulations governing those self-governing lands that had been brought into the Netherlands Indies as a result of the Korte Verklaring (short declaration) emphasized that 'the territory [gebied] of [these] lands includes no sea territory [zeegebied] of any kind' (Staatsblad, 1919, no. 822). Revisions to the government's contracts with the other self-governing realms contained articles stating that 'the district [landschap] [...] includes no sea territory [zeegebied]' (for example, Staatsblad, 1939, no. 612 (Kutai) and no. 613 (Bima)). 
No. 7295. ZEEPRODUCTEN. SPONZENVISSCHERIJ. TERRITORIALE ZEE. CONCESSIE-BELASTING? ZELFBESTUREN. Exploratie en exploitatie van de producten der zeeën langs de kusten van zelfbesturende landschappen. Concessieverleening niet te rekenen onder belastingheffing.

I.

Naar aanleiding van eene door het Inlandsch zelfbestuur van Goenoeng Taboer aan den Heer X. uitgegeven concessie tot het visschen naar sponzen in de zee langs de kusten van dat landschap en van de daartoe behoorende eilanden binnen een afstand van niet meer dan-drie Engelsche zeemijlen, werd den Resident der Zuideren Oosterafdeeling van Borneo bij missive van den $1^{\text {en }}$ Gouvernenements Secretaris van 15 Juli 1910 nः 1591 o.m. het volgende medegedeeld.

$$
\text { No. } 1591 .
$$

Buitenzorg, den $15^{\text {den }}$ Juli 1910.

\author{
Aan \\ den Resident der Zuider- en Oosterafdeeling \\ van Borneo.
}

Vóórdat tot de uitvaardiging van de sedert in Staatsblad 1902 nः 4 opgenomen bepalingen op het visschen naar parelschelpen, paarlemoerschelpen en tripang werd overgegaan, heeft het 0 . m. een punt van overweging uitgemaakt of bij het Gouvernement dan wel bij het betrokken zelfbestuur het recht berustte op de zeestrook van drie Engelsche zeemijlen breedte langs de kusten van een zelfbesturend landschap.

Die overweging leidde toen tot de uitspraak van den Minister van Koloniën dat bedoeld $\mathrm{recht}$ in zoodanig zeegebied eenig en alleen bij het Gouvernement berust (vgl. blz. 26 van het Tweede Gedeelte B der gedrukte Nota over politiek beleid en bestuurszorg), en krachtens dat recht het Gouvernement bevoegd is de visscherij en de inzameling van andere producten in zulk eene zeestrook te regelen zooals het Hem goeddunkt $\left.{ }^{(}{ }^{1}\right)$. Dat het niettemin wensche-

( $\left.{ }^{1}\right)$ Vgl. blz. $7 / 8$ van de dépêche des Ministers van 20 September 1902, Litt. $\mathrm{A}^{3}$ en $\mathrm{A}^{1}, \mathrm{n}^{0}$. 34/2418, o.a. verhandeld bij de dezerzijdsche circulaire van 2 Mei $1903 \mathrm{n}^{\circ}$. 1470, vgl. voor zoover betreft het beschikkingsrecht over de producten onder den bodem der territoriale zeestrook ook blz. 78 van het Tweede Gedeelte B. juncto blz. 73 van het Tweede Gedeelte A. der bovengenoemde Nota.

Supplement 7295, Bijblad op het Staatsblad van Nederlandsch-Indië 44 
that 'as a favour the self-governing realms would be allowed to dispose over fishing rights in so far as they had already in practice been exercising rights in relation to the sea adjacent to their lands or they thought they had a claim to these rights'. ${ }^{5}$ At this point we see how historians can read a passage in very different ways. For me the phrase 'as a favour' affects the tone of the whole statement: the Netherlands Indies government saw itself as having the ultimate authority over the waters washing the shores of the self-governing realms. Resink acknowledges the phrase but argues that what mattered was the fact that some of these realms continued to exercise rights over the exploitation of marine resources and the Dutch recognized these rights. Supplement 7295 goes on to state that the governor-general had no objection to the sultan of Gunung Tabur granting 'Mr X' permission to collect sponges or the ruler of Riau granting a permit to 'Messrs $X^{\prime}$ to undertake an investigation of sponges in the Riau-Lingga Archipelago. Noting that statute no. 4 did not deal with sponges, Resink (1968:127) concludes that:

On the basis of the 1910 supplement it might be argued that with regard to pearlshell fishing this right [to grant permits] was granted the rulers by way of a favour, but in the case of other sea products, and in particular sponges, there is no reason to believe that at that time there had ever been any question of taking away the right, then restoring it as a favour.

If we accept this reasoning, then we can agree that up until 1910 the rulers of Gunung Tabur and Riau retained the right to grant permits to collect, or explore for, sponges in the waters adjacent to their land territories. But can we then conclude, as Resink does a few lines later, that these two realms had territorial waters at this time? Can the existence of territorial waters hang by such a slender thread?

The answer to this question depends of course on what we mean by territorial waters. If the argument I have just summarized is any guide, Resink regards any exercise of jurisdiction in the sea as implying the existence of territorial waters. Indeed, this impression is confirmed by a comment he makes earlier in the same article that in the late 1800s 'opium traders, pirates, slavers, foreign criminals, pearl-divers, and sponge-fishers' were drawn 'little by little [...] into the territorial waters (in the sense of a sphere of Dutch maritime jurisdiction)' of the Netherlands Indies (Resink 1968:120). My own view is that this is much too broad a conception of territorial waters. In the period Resink is writing about there was intense debate in Europe not only about how far a state's territorial waters extended out to sea but also about just how much jurisdiction states could rightfully exercise over these waters. ${ }^{6}$ Nevertheless,

5 Bijblad op het Staatsblad van Nederlandsch-Indie, 1911, pp. 351-2. For a detailed account of the debates that led to these decisions, see Teitler 1994:37-54.

6 For an overview, see Swarztrauber 1972. 
most of those taking part in this debate shared two basic ideas. The first was that states exercised sovereignty over their territorial waters just as they did over their land and that they could regulate what went on in these waters as they wished, except in so far as they had acknowledged international conventions such as the right of innocent passage by foreign vessels. And the second was that these waters were demarcated in some way, whether by the range of a cannon, the range of vision, or by any one of several fixed distances from the shore, even if there was little agreement on which of these methods to apply (though by the 1880s the three-mile limit was becoming more and more widely adopted). If we accept this understanding of territorial waters, then the cases of Gunung Tabur and Riau that Resink cites merely demonstrate that their rulers exercised jurisdiction over the exploitation of certain marine resources. It does not necessarily imply that they regarded the waters in which these resources were located as part of their sovereign territory (just as today a state's exclusive right to exploit marine resources out to 200 nautical miles from the coast does not imply full sovereignty over those waters ${ }^{7}$ ) or, if they did, that they had any conception of the extent of the waters over which they claimed sovereign rights. In short, we cannot conclude from these two cases (or any other cases of rulers granting rights to exploit marine resources) that they had territorial waters.

But even if there are problems with Resink's argument, could it be that some self-governing realms did have territorial waters? Clearly, in my view, they did not after 1902, simply because the Netherlands Indies government so categorically quashed any pretensions these realms may have had to territorial waters up to that time. One senses that in his efforts to assert the existence of indigenous sovereignty as far into the colonial period as possible Resink eagerly latched on to any evidence he could that might help him achieve that goal. But is it possible that some self-governing realms had territorial waters before 1902 ? Fortunately, we are able to examine this possibility by making use of a broader range of sources than Resink had access to. In particular, several substantial files in the Ministry of Colonies archives shed light on this question. Two of these files deserve special mention. One contains a summary of responses to a questionnaire that the government sent out to officials in outlying areas in 1893 asking them, among other things, whether the areas for which they were responsible had potentially profitable pearl banks, whether, if they did, these banks fell within the 'sea territory' (territoriaal zeegebied) of these realms, and whether the indigenous authorities in those areas exercised rights of allocation

7 Under the United Nations Convention on the Law of the Sea, states have 'sovereignty' over their territorial seas just as they do over their land territory (article 2), whereas in their exclusive economic zones they have 'sovereign rights for the purpose of exploring and exploiting, conserving and managing the natural resources' (article 56), at http://www.un.org/Depts/los/index.htm. 
over resources off their shores. ${ }^{8}$ The other important file deals with questions raised by an application by a European mining company to mine tin in shallow water next to the island of Singkep, which was within the realm of the sultan of Riau-Lingga. ${ }^{9}$ Taken as a whole, the Ministry of Colonies files as well as a small number of published sources suggest two important points.

The first point is that many rulers exercised rights over the exploitation of marine resources of the type Resink deduced from statute no. 4 and supplement 7295. The sultans of Ternate and Tidore, for example, had a clear understanding about which pearl banks fell within their respective realms. ${ }^{10}$ The sultan of Ternate collected a small annual tribute from the pearl banks of the Sula Islands, where he held the exclusive right to fish for pearl-shell and sea cucumbers in waters more than three fathoms deep. ${ }^{11}$ Similarly, the various rulers of eastern Borneo imposed a levy on local people according to the amount of sea cucumbers or shell they collected. They also demanded a fixed fee from Bajau fishers who came from Sulu to collect sea cucumbers on Muaras and Maratua reefs, which lie out in the Celebes Sea about fifty kilometres from the coast of Borneo. According to the summary of the questionnaire, the income from certain reefs went directly to the rulers personally, while that from other reefs helped to cover the costs of the realm (negeri). ${ }^{12}$ To give one more example, the rulers along the East Coast of Sumatra levied various taxes on fishing in nearby waters, while in 1891 the sultans of Deli and Serdang granted a European the exclusive right to investigate the potential of the pearl-shell fishery off their coasts. ${ }^{13}$ One ruler of a self-governing realm, it should be mentioned, had lost rights he had once enjoyed: in 1863 the government in Batavia took over the sultan of Siak's right to tax the lucra-

8 'Résumé van de antwoorden der betrokken hoofden van gewestelijk bestuur op de dezerzijdsche circulaire van 4 April 1893 no. 1986 betreffende het visschen van parelschelpen, parelmoerschelpen en tripang in de territoriale wateren in Nederlandsch-Indië' (hereafter Résumé), Verbaal (hereafter Vb.) 18-9-1896, no. 48, inventarisnummer (hereafter inv.) 5083, in: Nationaal Archief, The Hague (hereafter NA), Archief Ministerie van Koloniën (hereafter Min. Kol.) 1850-1900, nummer toegang 2.10.02. Here I follow Peter Burns (2004:15) in translating the slippery concept of recht van beschikking or beschikkingsrecht as 'right of allocation'. Resink (1968:125) refers to this questionnaire, which is mentioned in supplement 7295. Resink's translator renders territoriaal zeegebied as 'maritime jurisdiction'.

9 Vb. 20-9-1902, no. 34, inv. 143, in: NA, Archief Min. Kol., 1900-1963, nummer toegang 2.10.36.04.

10 'Resumé', pp. 12-3, Vb. 18-9-1896, no. 48, inv. 5083, in: NA, Archief Min. Kol. 1850-1900, nummer toegang 2.10.02.

11 Resident of Ternate to governor-general, 2-9-1893, Vb. 11-1-1894, no. 51, inv. 4775, in: NA, Archief Min. Kol. 1850-1900, nummer toegang 2.10.02. See also ‘Resumé', p. 36, Vb. 18-9-1896, no. 48, inv. 5083, in: NA, Archief Min. Kol. 1850-1900, nummer toegang 2.10.02.

12 'Resumé', pp. 33-5, Vb. 18-9-1896, no. 48, inv. 5083, in: NA, Archief Min. Kol. 1850-1900, nummer toegang 2.10.02.

13 'Resumé', pp. 2-4, 16, 25, Vb. 18-9-1896, no. 48, inv. 5083, in: NA, Archief Min. Kol. 1850-1900, nummer toegang 2.10 .02 . 
tive terubuk (shad) fishery in the strait between Bengkalis and the mainland of Sumatra (Gramberg 1880:336-7). In general, however, the government did nothing to restrict the rights of the self-governing realms to marine resources. Indeed, officials made a point of recognizing these rights. Thus, when a European applied to the government for the right to collect pearl oysters in the Sula Islands, the resident of Ternate pointed out that because these islands 'are not under our direct rule' he would have to apply to the sultan. ${ }^{14}$ All this confirms, at least for the 1890s, that many rulers did indeed exercise some jurisdiction over the waters adjacent to their land territories.

Second, this body of evidence suggests that some realms in fact had territorial waters. According to the summary, the rajas of East Sumatra believed that 'their sea territory [zeegebied] extends out as far as local fishers can operate' and that therefore even pearl banks far from the coast belonged to their 'domain' ${ }^{15}$ According to Van Vollenhoven (1931:162), the regional lords in Aceh had at one time received letters from the sultan recognizing as part of their territories the sea 'out as far as one can fish with a drag net'. In the 1890s the regional lords, whom the Dutch sought as allies in their war to take control of Aceh, continued to 'exercise rights over the sea between the shore and the labuan pukat (fishing boundary)', which varied from one place to another but generally lay about two kilometres from the shore. ${ }^{16}$

The Riau-Lingga sultanate provides probably the clearest case of the existence of territorial waters. In 1899 the resident of Riau reported that the sultan claimed 'territorial rights' (gebiedsrechten) that extended out first to the lowwater mark (tubier), then covered all flats and reefs in nearby waters, included the sea between the surrounding islands that could be seen with the naked eye, and, finally, extended out to the horizon as seen from the shore. The extent of a maritime territory determined by the range of vision can of course vary greatly depending on where, how, and under what conditions the observation is made, but if it was made on a clear day by a fairly tall person standing at sea level at the edge of the water, then the area over which the sultan claimed jurisdiction extended out to about three nautical miles from the islands of the Riau-Lingga Archipelago (Swarztrauber 1972:41). The resident commented that whatever the terms of the various treaties between the sultanate and the Netherlands, the sultan 'in fact conducts himself as if he exercises dominion [heerschappij] over the territorial sea'. Specifically, the sultan not only issued

14 Resident of Ternate to governor-general, 2-9-1893, Vb. 11-1-1894, no. 51, inv. 4775, in: NA, Archief Min. Kol. 1850-1900, nummer toegang 2.10.02. See also 'Resumé', pp. 13, 41-2, Vb. 18-91896, no. 48, inv. 5083, in: NA, Archief Min. Kol. 1850-1900, nummer toegang 2.10.02, regarding the sultan of Bacan's grant of a pearling concession to a European firm.

15 'Resumé', p. 16, Vb. 18-9-1896, no. 48, inv. 5083, in: NA, Archief Min. Kol. 1850-1900, nummer toegang 2.10.02.

16 'Resumé', pp. 22-3, Vb. 18-9-1896, no. 48, inv. 5083, in: NA, Archief Min. Kol. 1850-1900, nummer toegang 2.10.02. A more literal translation of labuan pukat would be 'net harbour'. 
permits for the operation of fishing stakes and for collecting sea cucumbers, agar-agar, turtle shell, and other sea products but also demanded payment for collecting limestone on coral reefs, banned the placing of traps in areas where agar-agar was collected, tried cases of misdeeds committed by his subjects 'in these territorial waters', and flew only his own flag (rather than that of the Netherlands Indies as well) on his ships. ${ }^{17}$ In short, the evidence is overwhelming that at least in his own eyes the sultan of Riau-Lingga regarded himself as having territorial waters over which he exercised sovereignty.

Yet another case for which there is evidence of territorial waters is Bali, which the Dutch did not fully incorporate into the Netherlands Indies until 1908. According to Korn, whom Resink $(1968: 127,199)$ cites, the various princes on the island considered a strip of the sea to be part of their realms, and in the case of Badung various sections of this strip were assigned to members of the aristocracy. Korn (1932:440) also cites a report of the Dutch expedition against Badung in 1906 that states that the princes of Badung denied the Dutch the right to collect any duties on ships in 'Badung's waters'. The report itself adds the comment that 'in their judgement we should levy no duties in the territorial waters [territoriale wateren] of Badung' (Van Rietschoten 1910:11). The report says nothing about how extensive these territorial waters were or how they were demarcated, but we can conclude that the princes had a clear conception of the waters washing their shores as being part of their realms.

Finally, there is evidence of a more general nature about the existence of territorial waters in the Indies. In 1898 the Raad van Nederlandsch-Indië (Council of the Netherlands Indies), which advised the governor-general on major policy questions, argued that it was only natural that realms that depended so much on the sea for their livelihoods would have territorial waters. Somewhat more specifically, one member of the council, W.J.M. Michielsen, reported that 'the rajas of the native states that have coasts commonly speak of saya punya laut [my sea]'. He added that whenever a question arose whether a particular islet visible from the shore belonged to one or the other of two bordering realms, it was decided simply by extending the land border out to the horizon. This line in the sea was in fact, he asserted, regarded as the boundary between the sea territories of the two realms. ${ }^{18}$ Although Michielsen gave no examples of such boundaries, it at least appears likely that in addition to the cases I cited earlier - the East Coast of Sumatra, Aceh,

17 Resident of Riau to governor-general, 30-5-1899, Vb. 20-9-1902, no. 34, inv. 143, in: NA, Archief Min. Kol., 1900-1963, nummer toegang 2.10.36.04. The resident forwarded to Batavia a transliteration of the first article, a proclamation dealing at least in part with these matters that the sultan issued on 1 Muharram 1300 (12 November 1882), but this document was not sent on to the Ministry of Colonies. So far I have not located any documents dealing with maritime claims that were produced by indigenous authorities.

18 Advies van den Raad van Nederlandsch-Indië, 25-8-1899, Vb. 20-9-1902, no. 34, inv. 143, in: NA, Archief Min. Kol., 1900-1963, nummer toegang 2.10.36.04. 
Bali, and particularly Riau-Lingga - several other self-governing realms had the notion of territorial waters in the 1890s.

So where does this leave Resink's argument? At least for the period before 1902 Resink's conclusion that some self-governing realms had territorial waters still stands, even if the method by which he reaches this conclusion is questionable. Moreover, again for the period before 1902, the fact that some realms had territorial waters lends support to Resink's broader argument about the autonomy of these realms. My own view, however, is that Resink could have made his case just as effectively without going to such lengths to deduce the existence of territorial waters. To demonstrate the autonomy of the various realms there is no need to show that they had territorial waters in the sense that Europeans understood this concept. The more important point is simply that at least until 1902 many of them exercised some form of jurisdiction over the seas washing their land territories, that they exercised this almost totally independently of the Netherlands Indies government, and that even from the point of view of the government they had every right to do so.

Thus, Resink's broader argument still stands without having to demonstrate that the self-governing realms had territorial waters. In a sense we would not expect them to have them. Just as polities in this part of the world tended not to have a clear conception of their borders on land, we should hardly expect them to in the water. ${ }^{19}$ But the fact remains that at least one of them - RiauLingga - did have territorial waters by almost any definition of that concept, and that a few others almost certainly did as well. When and under what circumstances did Riau-Lingga (and most likely others as well) adopt the idea of territorial waters? It is unlikely that they took the idea from the Dutch, for as mentioned the Netherlands Indies government took very little interest in defining its territorial waters until the late 1800s and in so far as it did claim various jurisdictions in the sea it demarcated them using the nautical mile as the unit of measure. Another possibility is that the sultanate was following British practice in the nearby Straits Settlements. Under the terms of their 1824 treaty with the sultan and temenggong of Johor, the British gained 'full sovereignty' not only over the island of Singapore but also over 'the adjacent seas, straits, and islets, to the extent of ten geographical miles, from the coast of the main Island' (Buckley 1902:168). In the 1860s the British interpreted the treaty as giving them jurisdiction everywhere in the narrow straits between Singapore and Johor. The temenggong, however, protested that the British claim violated international law, and pointed out that even official British maps 'show a line running through the straits as if to mark the boundary

19 My wording suggests that the way people regarded boundaries in the sea was an extension of the way they conceived divisions between polities on land. Trocki (2005:2) raises the possibility that it may have been the other way around, arguing that 'the openness and boundless aspect of the sea militated against seeing the world as divided into discreet compartments'. 
of jurisdiction between Johore and Singapore'.$^{20}$ The colonial authorities in Singapore eventually accepted the temenggong's position and at about the same time limited the extent of Singapore's territorial waters to three miles (Turnbull 1959:50; Trocki 1979:132-6, 2005). What is striking in this case is the temenggong's awareness of international conventions regarding the demarcation of waters between states. The way the sultan of Riau-Lingga defined his territorial waters had very little to do with any widely adopted practice at that time. Nevertheless, it was based on the same principle by which the Scots once defined their exclusive fishing zone out to a 'land kenning' from the coast ${ }^{21}$ and the English demanded in the 1700s that ships from Tripoli never come 'in sight of' their garrison at Tangier (Swarztrauber 1972:37). Thus it is possible that the early rulers of Riau-Lingga adopted the idea from European practice at some stage. The remaining possibility of course is simply that they came up with the idea themselves. Swarztrauber (1972:42-3) argues that the definition of territorial waters by the range of vision was often associated with efforts by states to protect themselves from outside threats. As these speculations suggest, we have barely begun to explore the kinds of maritime jurisdictions exercised by the states in the island world before 1900. That we have explored it at all is largely due to Resink's pioneering attempt to make out the claims over the sea and its resources made by the people of that time.

20 Letters to the government secretary, Straits Settlements, May 1865 (day of month unclear on microfilm) and 7 April 1865, in CO273/15 (Straits Settlements Original Correspondence, Colonial Office, National Archives of the United Kingdom, consulted on microfilm at the National Library of Australia).

21 A land-kenning - usually taken to be fourteen miles - was defined by the principle that foreign fishermen could not operate closer to the shore than where they could see the land from the top of their masts (Fulton 1911:84).

\section{References}

\section{Unpublished sources}

Nationaal Archief, The Hague

Archief Ministerie van Koloniën 1850-1900, nummer toegang 2.10.02

Archief Ministerie van Koloniën 1900-1963, nummer toegang 2.10.36.04

\section{Published sources}

Buckley, Charles Burton

1902 An anecdotal history of old times in Singapore. Singapore: Fraser and Neave. [Reprinted Kuala Lumpur and Singapore: University of Malaya Press, 1969.] 
Burns, Peter

2004

The Leiden legacy; Concepts of law in Indonesia. Leiden: KITLV Press. [Verhandelingen 191.]

Fulton, Thomas Wemyss

1911 The sovereignty of the sea; An historical account of the claims of England to the dominion of the British seas, and of the evolution of the territorial waters, with special reference to the rights of fishing and the naval salute. Edinburgh: Blackwood.

Gramberg, J.S.G.

1880 'De visscherij en bezwering van troeboek', Indische Gids 2, II:331-46.

Korn, V.E.

1932 Het adatrecht van Bali. Tweede herziene druk. 's-Gravenhage: Naeff. [First edition 1924.]

Resink, G.J.

1968 Indonesia's history between the myths; Essays in legal history and historical theory. The Hague: Van Hoeve. [Selected Studies on Indonesia 7.]

Rietschoten, C.H. van

1910 'Algemeen verslag van den chef van den staf der expeditie naar Bali, 10 September-30 October 1906', Indisch Militair Tijdschrift, Extra-bijlage 27.

Swarztrauber, Sayre A.

1972 The three-mile limit of territorial seas. Annapolis, MD: Naval Institute Press.

Teitler, G.

1994 Ambivalentie en aarzeling; Het beleid van Nederland en Nederlands-Indie ten aanzien van hun kustwateren, 1870-1962. Assen: Van Gorcum. [Koninklijke Nederlandse Akademie van Wetenschappen, Werken uitgegeven door de Commissie voor Zeegeschiedenis 19.]

Trocki, Carl A.

1979 Prince of pirates; The temenggongs and the development of Johor and Singapore 1784-1885. Singapore: Singapore University Press.

2005 'The question of pre-colonial borders and Malay political culture'. [Manuscript.]

Turnbull, C.M.

1959 'The Johore gambier and pepper trade in the mid-nineteenth century', Journal of the South Seas Society 15-1(June):43-55.

Vollenhoven, C. van

1931 Het adatrecht van Nederlandsch-Indië. Vol. 1. Leiden: Brill. 


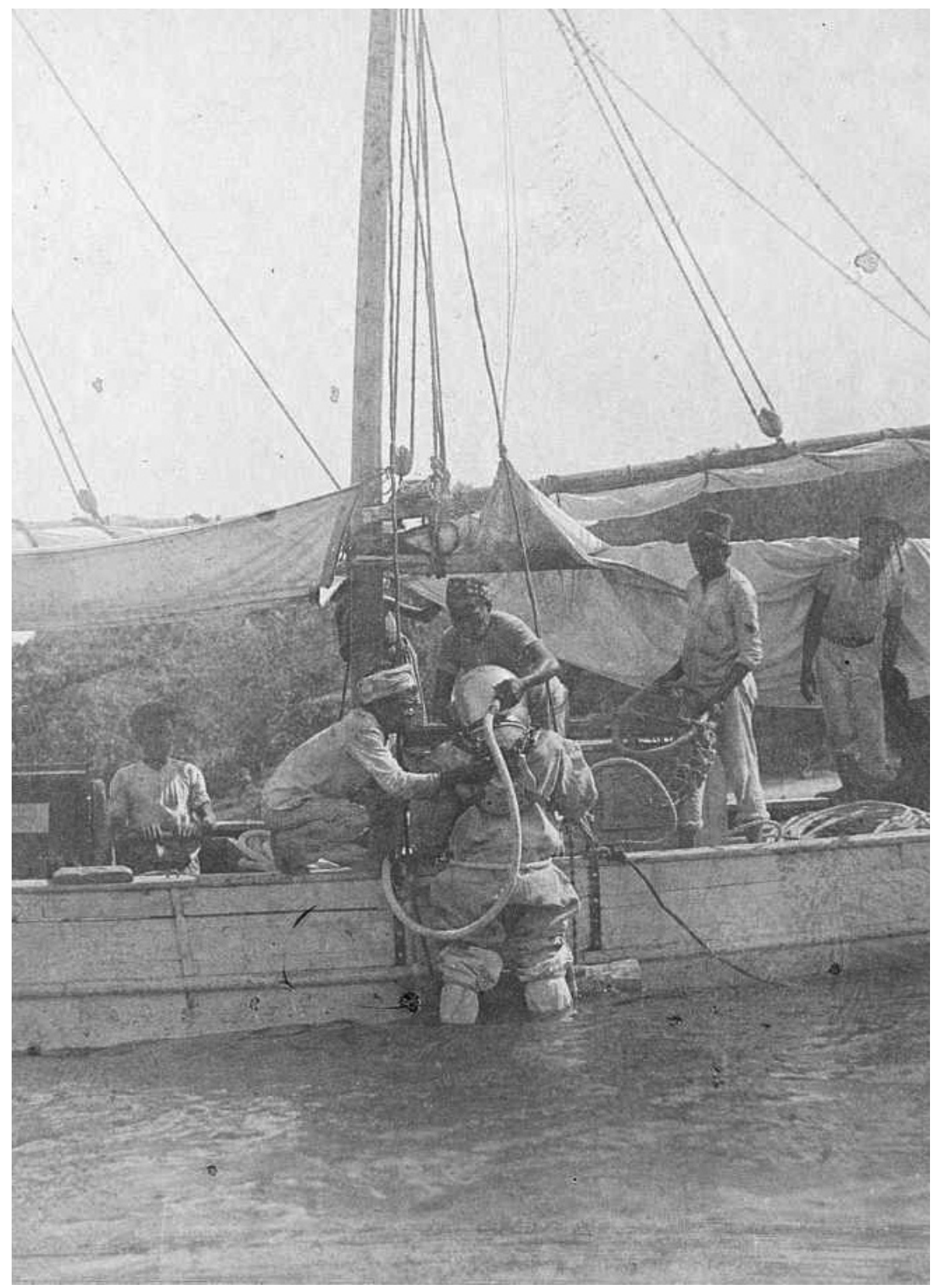

Pearl-diver enters the water, Alor, 1898 (KITLV, 4818) 


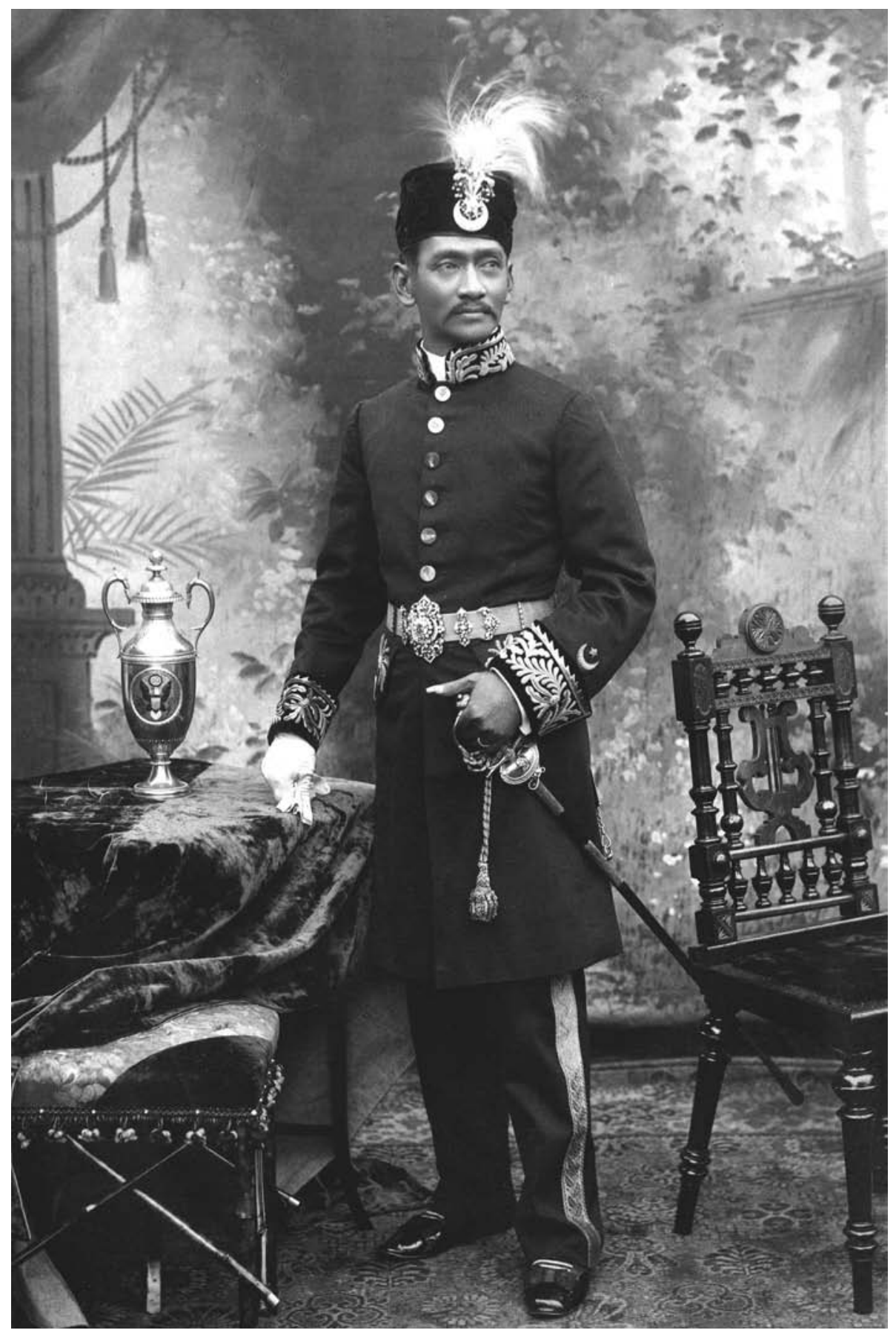

Abdul Rachman Maadlam Syah, sultan of the Riau-Lingga Archipelago, 1904 (KITLV, 19191) 


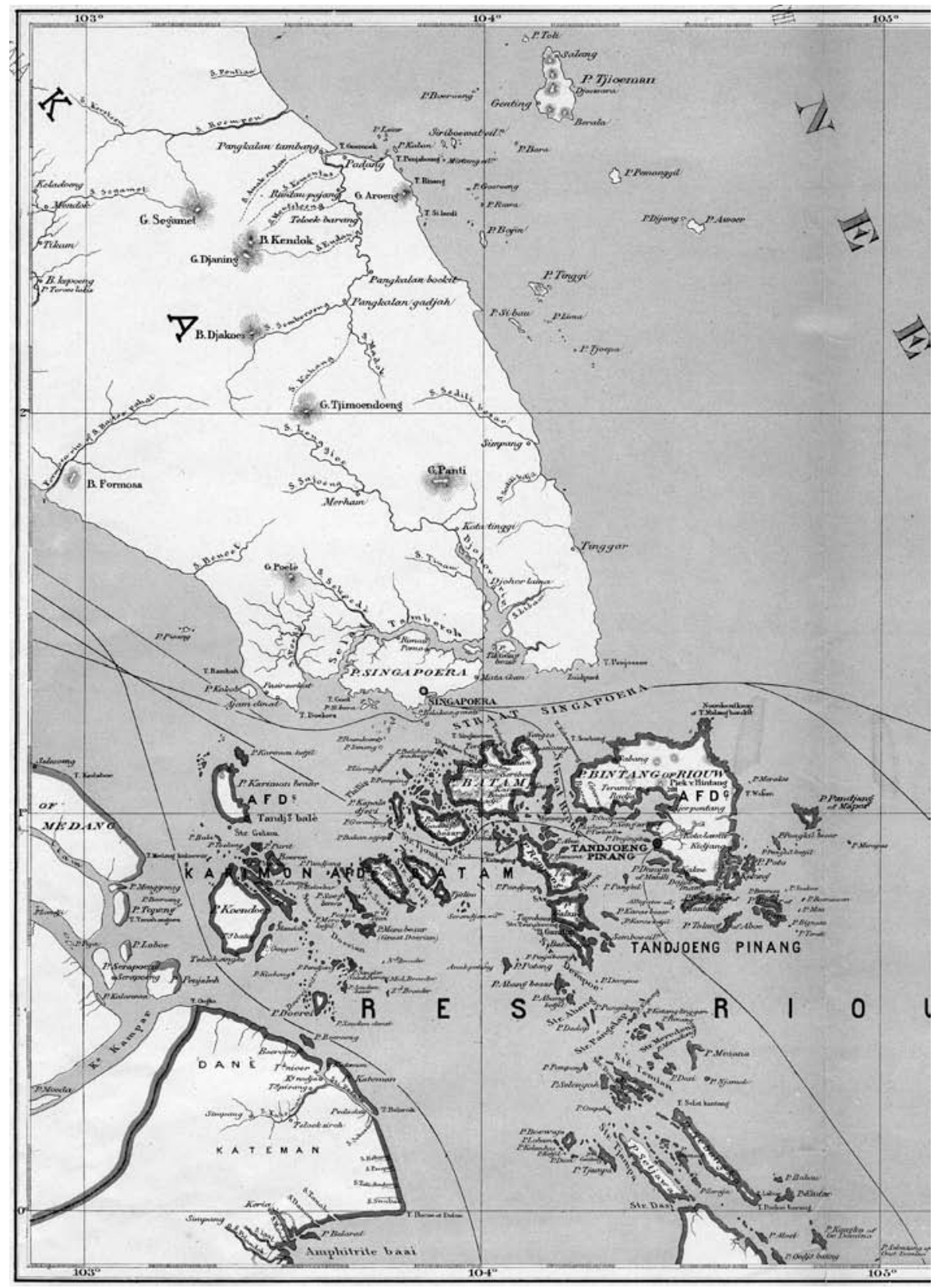

Detail of map from the bundle of maps: Soematra, Bangka en de Riouw-Lingga Archipel, bewerkt door Dr. I. Dornseiffen, Amsterdam, 1896, showing the Riau-Lingga Archipelago around $1^{\circ}$ latitude (KITLV, D C 24,1, blad 6) 


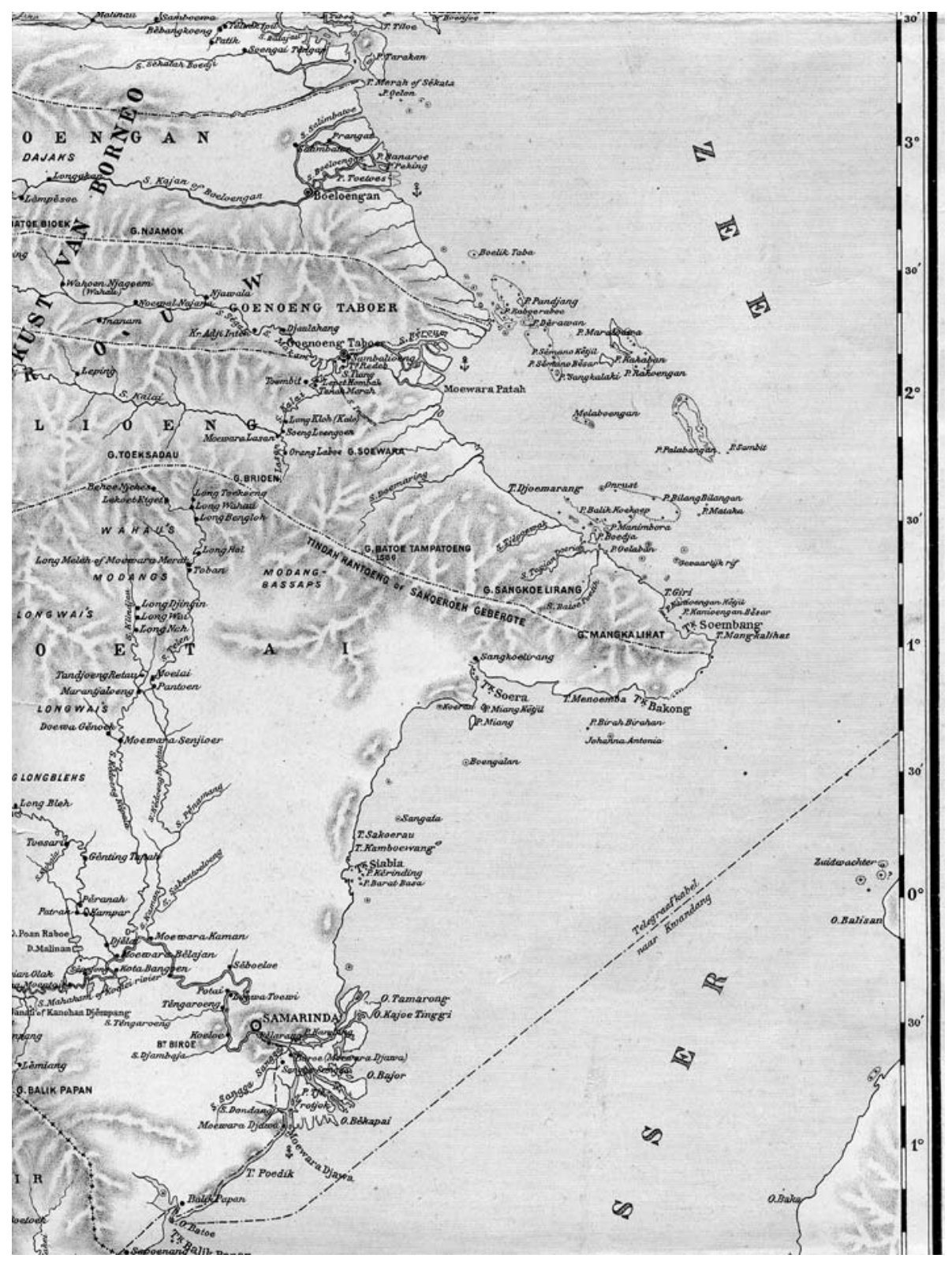

Detail of Kaart van het eiland Borneo (Map of the island of Borneo), Batavia, 1902, showing Gunung Tabur between $2^{\circ}$ and $3^{\circ}$ latitude (KITLV, D B 39, 7) 